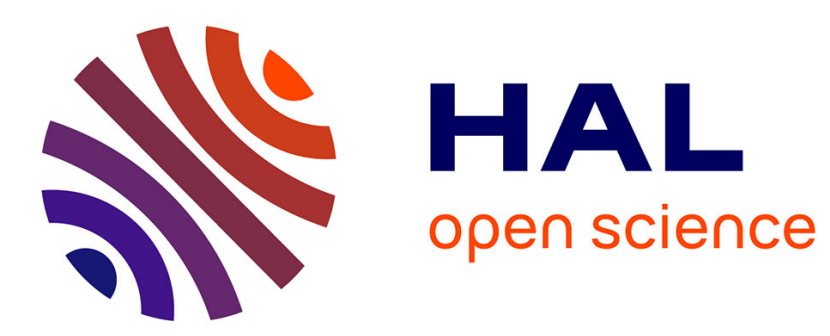

\title{
New cobaltite materials containing CdI2-type layers: Synthesis and structures of $\mathrm{Ba} 2 \mathrm{Co} 4 \mathrm{ClO} 7$ and $\mathrm{Ba} 2 \mathrm{Co} 4 \mathrm{BrO} 7$
}

Matthieu Kauffmann, Nathalie Tancret, Francis Abraham, Pascal Roussel

\section{- To cite this version:}

Matthieu Kauffmann, Nathalie Tancret, Francis Abraham, Pascal Roussel. New cobaltite materials containing CdI2-type layers: Synthesis and structures of $\mathrm{Ba} 2 \mathrm{Co} 4 \mathrm{ClO} 7$ and $\mathrm{Ba} 2 \mathrm{Co} 4 \mathrm{BrO} 7$. Solid State Sciences, 2007, 9, pp.885-894. 10.1016/j.solidstatesciences.2007.06.012 . hal-00187411

\section{HAL Id: hal-00187411 https://hal.science/hal-00187411}

Submitted on 15 Nov 2007

HAL is a multi-disciplinary open access archive for the deposit and dissemination of scientific research documents, whether they are published or not. The documents may come from teaching and research institutions in France or abroad, or from public or private research centers.
L'archive ouverte pluridisciplinaire HAL, est destinée au dépôt et à la diffusion de documents scientifiques de niveau recherche, publiés ou non, émanant des établissements d'enseignement et de recherche français ou étrangers, des laboratoires publics ou privés. 


\title{
New cobaltite materials containing $\mathrm{CdI}_{2}$-type layers: synthesis and
}

\section{structures of $\mathrm{Ba}_{2} \mathrm{Co}_{4} \mathrm{ClO}_{7}$ and $\mathrm{Ba}_{2} \mathrm{Co}_{4} \mathrm{BrO}_{7}$}

\author{
Kauffmann Matthieu, Tancret Nathalie, Abraham Francis, Roussel Pascal * \\ UCCS, Equipe Chimie du Solide, CNRS UMR 8181, ENSC Lille - UST Lille, \\ BP 90108, 59652 Villeneuve d'Ascq cedex, France
}

Telephone number: (+33) (0)320336434 - Fax number: (+33) (0)320436814

* Corresponding author: pascal.roussel@ensc-lille.fr

\begin{abstract}
Single crystals of the title compounds were prepared by solid-solid reaction using $\mathrm{BaCl}_{2}$ or $\mathrm{BaBr}_{2}$ flux at $1100^{\circ} \mathrm{C}$. The structures of these two new cobaltites were solved and refined in the trigonal symmetry with space group $\mathrm{R} \overline{3} \mathrm{~m}$ : $a=5.716(2) \AA, c=45.01(3) \AA$ for $\mathrm{Ba}_{2} \mathrm{Co}_{4} \mathrm{ClO}_{7}$ and $\mathrm{a}=5.7434(5) \AA, \mathrm{c}=46.151(9) \AA$ for $\mathrm{Ba}_{2} \mathrm{Co}_{4} \mathrm{BrO}_{7}$. The two compounds are isostructural and their structures can be considered as the intergrowth along [001] of hexagonal blocks $\left(\mathrm{Ba}_{2} \mathrm{Co}_{8} \mathrm{O}_{14}\right)^{2-}$ built from a close-packing of $\left[\mathrm{O}_{4}\right]$ and $\left[\mathrm{BaO}_{3}\right]$ layers with octahedral and tetrahedral cobalt, separated by fluorite-type double layers $\left(\mathrm{Ba}_{2} \mathrm{Cl}_{2}\right)^{2+}$ or $\left(\mathrm{Ba}_{2} \mathrm{Br}_{2}\right)^{2+}$. The main difference between $\mathrm{Ba}_{2} \mathrm{Co}_{4} \mathrm{ClO}_{7}$ and $\mathrm{Ba}_{2} \mathrm{Co}_{4} \mathrm{BrO}_{7}$ is due to the fluoritetype layers: $\left(\mathrm{Ba}_{2} \mathrm{Cl}_{2}\right)^{2+}$ double layers are perfectly ordered while $\left(\mathrm{Ba}_{2} \mathrm{Br}_{2}\right)^{2+}$ blocks are affected by a structural disorder through the bromine atoms.
\end{abstract}

Keywords: Cobaltites, Barium cobalt oxyhalide, Hexagonal perovskite, Maximum Entropy Method (MEM), Crystal structure 


\section{Introduction}

Numerous perovskite-related materials exhibit unusual and interesting properties such as high Tc superconductivity, piezo-electricity or colossal magneto-resistance among others $[1,2]$. These phenomena are still insufficiently understood and the comprehension of the mechanism leading to these spectacular properties is of particular interest for the scientists working in the area of new materials. Therefore perovskite-type compounds are intensively studied. In this way, for instance, the well-known manganites have been largely investigated because of their interesting properties: a wide range of valence states and the possibility to adopt several polyhedral configurations as, for example, octahedral or tetrahedral environments. The research on manganites materials has led, for example, to the discovery of colossal magneto-resistance $[3,4]$. Compared to these compounds, the cobaltites exhibit one additional degree of freedom provided by the cobalt spin-state. Indeed, $\mathrm{Co}^{3+}$ atoms $\left(3 \mathrm{~d}^{6}\right)$ in $\mathrm{O}_{6}$ octahedral environment can adopt either the low spin LS $\left(\mathrm{t}_{2 \mathrm{~g}}{ }^{6} \mathrm{e}_{\mathrm{g}}{ }^{0}, \mathrm{~S}=0\right)$, the intermediate spin IS $\left(\mathrm{t}_{2 \mathrm{~g}}{ }^{5} \mathrm{e}_{\mathrm{g}}{ }^{1}, \mathrm{~S}=1\right)$ or the high spin $\mathrm{HS}\left(\mathrm{t}_{2 \mathrm{~g}}{ }^{4} \mathrm{e}_{\mathrm{g}}{ }^{2}, \mathrm{~S}=2\right)$ configurations $[5,6]$. The possibility to stabilize several spin configurations is of great interest, as illustrated for instance in the $\mathrm{LnBaCo}_{2} \mathrm{O}_{5.5}$ series where the metal-insulator transition is due to a spin-blockade mechanism attributed to the presence of high-spin and low-spin of $\mathrm{Co}^{3+}$ ions [7]. Moreover, the discovery of large thermopower properties in $\mathrm{Na}_{\mathrm{x}} \mathrm{CoO}_{2}$ [8] has reinforced the interest of the research in cobaltites materials. In this series of layered cobalt oxides, candidates for thermoelectric materials, $\mathrm{CdI}_{2}$-type layers were proposed to be at the origin of these interesting physical properties.

Recently, Sun et al. have reported the existence of a new barium cobaltite series $\mathrm{Ba}_{n+1} \mathrm{Co}_{n} \mathrm{O}_{3 \mathrm{n}+3}\left(\mathrm{Co}_{8} \mathrm{O}_{8}\right)$, in which $\mathrm{Ba}_{2} \mathrm{Co}_{9} \mathrm{O}_{14}$ and $\mathrm{Ba}_{3} \mathrm{Co}_{10} \mathrm{O}_{17} \quad(\mathrm{n}=1$ and $\mathrm{n}=2$ terms, respectively) where isolated [9]. These structures have been described as intergrowth of 
perovskite layers and $\mathrm{CdI}_{2}$-type oxide layers. These $\mathrm{CoO}_{2}$ layers (of $\mathrm{CdI}_{2}$-type) are also present in the misfit layered cobaltites series $\left[\mathrm{Tl}_{1-\mathrm{x}} \mathrm{Sr}_{2+\mathrm{x}-\mathrm{y}} \mathrm{Co}_{\mathrm{y}} \mathrm{O}_{3}\right]\left[\mathrm{CoO}_{2}\right]_{\mathrm{z}}$ and seem to be responsible of the very interesting high thermopower or low resistivity properties of these materials [10].

In the present paper, we report on the synthesis and structural characterization of two new isostructural oxyhalide cobaltites, $\mathrm{Ba}_{2} \mathrm{Co}_{4} \mathrm{ClO}_{7}$ and $\mathrm{Ba}_{2} \mathrm{Co}_{4} \mathrm{BrO}_{7}$, which adopt hexagonal $18 \mathrm{R}$ structures (18R meaning that 18 layers are necessary to describe the unit cell in space group $\mathrm{R} \overline{3} \mathrm{~m}$ ). These structures can be described by the stacking along [001] of fluorite-type double layers $\left(\mathrm{Ba}_{2} \mathrm{Cl}_{2}\right)^{2+}$ or $\left(\mathrm{Ba}_{2} \mathrm{Br}_{2}\right)^{2+}$ and blocks $\left(\mathrm{Ba}_{2} \mathrm{Co}_{8} \mathrm{O}_{14}\right)^{2-}$ built up from $\mathrm{CdI}_{2}$-type oxide layers, which make them potential candidates for thermoelectric materials.

\section{Experimental}

\subsection{Synthesis}

$\mathrm{Ba}_{2} \mathrm{Co}_{4} \mathrm{ClO}_{7}$ and $\mathrm{Ba}_{2} \mathrm{Co}_{4} \mathrm{BrO}_{7}$ single crystals were grown using a flux technique. $\mathrm{A}$ 1:1:10 molar mixture of $\mathrm{BaCO}_{3}, \mathrm{Co}_{3} \mathrm{O}_{4}$ and $\mathrm{BaCl}_{2}, 2 \mathrm{H}_{2} \mathrm{O}$ or $\mathrm{BaBr}_{2}, 2 \mathrm{H}_{2} \mathrm{O}$ was well ground in an agate mortar and heated in air at $1100^{\circ} \mathrm{C}$ for 48 hours in an alumina crucible. The mixture was then slowly cooled at $30^{\circ} \mathrm{C} / \mathrm{h}$ to room temperature. After dissolving the excess of $\mathrm{BaCl}_{2}$ or $\mathrm{BaBr}_{2}$ with hot water, black hexagonal plate-like crystals of approximate size $0.1-2 \mathrm{~mm}$ were isolated from the reaction product.

Well-developed single crystals were analyzed by energy-dispersive X-ray spectroscopy on a JEOL JSM-5300 scanning microscope equipped with an IMIX system of Princeton Gamma Technology. Measurements revealed the presence of barium, cobalt, oxygen and chlorine or bromine for $\mathrm{Ba}_{2} \mathrm{Co}_{4} \mathrm{ClO}_{7}$ and $\mathrm{Ba}_{2} \mathrm{Co}_{4} \mathrm{BrO}_{7}$ respectively. Semi- 
quantitative analysis realized on several points of the crystals confirmed the formula of each compounds.

\subsection{Crystal structure determination}

For the structure determination, single crystals of $\mathrm{Ba}_{2} \mathrm{Co}_{4} \mathrm{ClO}_{7}$ and $\mathrm{Ba}_{2} \mathrm{Co}_{4} \mathrm{BrO}_{7}$ were selected, mounted on a glass fibre and aligned on a Bruker X8 APEX2 diffractometer. Intensities were collected at room temperature using $\operatorname{MoK} \alpha$ radiation $(\lambda=0.71073 \AA)$ selected by a graphite monochromator. The $\omega$-scan angle and the $D x$ parameter (distance between the single crystal and the CCD detector) were fixed, respectively, to $0.3^{\circ} /$ frame and $54 \mathrm{~mm}$ for $\mathrm{Ba}_{2} \mathrm{Co}_{4} \mathrm{ClO}_{7}$ and to $0.5^{\circ} /$ frame and $40 \mathrm{~mm}$ for $\mathrm{Ba}_{2} \mathrm{Co}_{4} \mathrm{BrO}_{7}$, depending on the crystal quality and spot shapes. For both compounds, acquisition time was 20 seconds per frame. The diffracted intensities were collected up to $2 \theta=62.46^{\circ}$ with 2763 reflections and a redundancy of 4.86 in the space group $\mathrm{R} \overline{3} \mathrm{~m}$ for $\mathrm{Ba}_{2} \mathrm{Co}_{4} \mathrm{ClO}_{7}$ and $2 \theta=56.88^{\circ}$ with 3512 reflections and a redundancy of 7.47 in the space group $\mathrm{R} \overline{3} \mathrm{~m}$ for $\mathrm{Ba}_{2} \mathrm{Co}_{4} \mathrm{BrO}_{7}$. After data collection, the intensities were integrated and corrected for Lorentz, polarisation and background effects using the Saint 7.12 software [11]. The SADABS 2006/1 program [12] was used to correct absorption effects using a semi-empirical method based on redundancy. Details of the data collection and refinements are given in Table 1 . The hexagonal unit-cell parameters were refined to $\mathrm{a}=5.716(2) \AA, \mathrm{c}=45.01(3) \AA$ and $\mathrm{a}=5.7434(5) \AA, \mathrm{c}=46.151(9) \AA$ for $\mathrm{Ba}_{2} \mathrm{Co}_{4} \mathrm{ClO}_{7}$ and $\mathrm{Ba}_{2} \mathrm{Co}_{4} \mathrm{BrO}_{7}$ respectively.

Crystal structures were determined for both compounds in the $\mathrm{R} \overline{3} \mathrm{~m}$ space group by direct methods using SIR97 program [13], which readily established the heavy atom positions ( $\mathrm{Ba}$, $\mathrm{Co}$ and $\mathrm{Cl}$ or $\mathrm{Br}$ ). Oxygen atoms positions were found by difference Fourier map calculations. Anisotropic displacement parameters were attributed to all atoms in the last 
cycles of refinement. Full-matrix least-squares structures refinements against $\mathrm{F}$ were carried out using the JANA2000 program [14].

As already reported in one of our previous paper [15], the introduction of bromine atoms in this type of layered compounds can lead to structural disorder. We thus undertook a Maximum Entropy Method (MEM) analysis of the diffraction data collected on $\mathrm{Ba}_{2} \mathrm{Co}_{4} \mathrm{ClO}_{7}$ and $\mathrm{Ba}_{2} \mathrm{Co}_{4} \mathrm{BrO}_{7}$. MEM is a model-free method which is used to calculate accurate electron densities in solids using experimental phased structure factors as input. This method has been proved to be particularly suited to determine structural aspects of disorder and anharmonic vibrations [16]. To calculate the precise electron density distribution, the MEM analysis was carried out using the computer program BAYMEM [17]. The total number of electrons in the unit cell has been fixed to $\mathrm{F}(000)$ values (1758 e- and 1866 e- for $\mathrm{Ba}_{2} \mathrm{Co}_{4} \mathrm{ClO}_{7}$ and $\mathrm{Ba}_{2} \mathrm{Co}_{4} \mathrm{BrO}_{7}$ respectively) and the unit cell was divided in a grid of $72 * 72 * 486$ pixels to ensure a good resolution (better than $0.1 \AA$ for the two studied compounds). All calculations were performed with an initial flat electron density with all the independent reflections. The

reliability factor of the MEM, $R_{M E M}=\frac{\sum\left|F_{o b s}-F_{M E M}\right|}{\sum\left|F_{o b s}\right|}$ is given in Table 1 ( $\mathrm{F}_{\text {obs }}$ is obtained by the structural refinement and $\mathrm{F}_{\mathrm{MEM}}$ is the structure factor calculated from the electron density obtained by the MEM).

\section{Results and discussion}

The atomic coordinates and anisotropic displacement parameters deduced from the single crystal refinements are listed in Table 2 and Table 3 for $\mathrm{Ba}_{2} \mathrm{Co}_{4} \mathrm{ClO}_{7}$ and $\mathrm{Ba}_{2} \mathrm{Co}_{4} \mathrm{BrO}_{7}$, respectively. Selected bond lengths and bond valence sums (BVS) are reported in Table 4 and Table 5. Views of the structures along (010) are represented Figure 1a and 1b. The two 
compounds are isostructural and can be described as perovskite-related materials with a 18layers stacking along the c-axis of $\left[\mathrm{O}_{4}\right],\left[\mathrm{BaO}_{3}\right]$ and $[\mathrm{BaX}](\mathrm{X}=\mathrm{Cl}$ or $\mathrm{Br})$ layers. In the stacking sequence, two $\left[\mathrm{O}_{4}\right]$ layers are sandwiched by two $\left[\mathrm{BaO}_{3}\right]$ layers, leading to the creation of octahedral and tetrahedral sites where the cobalt atoms are localized. These blocks are separated by double fluorite-type $\left(\mathrm{Ba}_{2} \mathrm{X}_{2}\right)^{2+}$ layers. Thus, the structure can be considered as the intergrowth of two different types of blocks represented by a (cccch'h') ${ }_{3}$ stacking sequence with the notation of Katz and Ward [18] (where h' denotes a lacunar [BaX] layer): one hexagonal close-packed block $\left(\mathrm{Ba}_{2} \mathrm{Co}_{8} \mathrm{O}_{14}\right)^{2-}$ and one fluorite-type double layers $\left(\mathrm{Ba}_{2} \mathrm{Cl}_{2}\right)^{2+}$ or $\left(\mathrm{Ba}_{2} \mathrm{Br}_{2}\right)^{2+}$.

$\left(\mathrm{Ba}_{2} \mathrm{Co}_{8} \mathrm{O}_{14}\right)^{2-}$ blocks have recently been evidenced in $\mathrm{Ba}_{2} \mathrm{Co}_{9} \mathrm{O}_{14}$ and $\mathrm{Ba}_{3} \mathrm{Co}_{10} \mathrm{O}_{17}[9$, 19]. These compounds have been described as intergrowth structures containing $\mathrm{CdI}_{2}$-type layers (formed from two close-packed oxygen layers) and perovskite-type layers (built from $\left[\mathrm{BaO}_{3}\right]$ layers) with either a single-octahedral layer $\left(\mathrm{Ba}_{2} \mathrm{Co}_{9} \mathrm{O}_{14}\right)$ or a double-octahedral layer $\left(\mathrm{Ba}_{3} \mathrm{Co}_{10} \mathrm{O}_{17}\right)$. The $\mathrm{CdI}_{2}$-type and the perovskite-type layers are connected together through a so-called "interface layer" containing octahedral and tetrahedral sites. Figure 2 presents the similarities between the structures of $\mathrm{Ba}_{2} \mathrm{Co}_{4} \mathrm{XO}_{7}(\mathrm{X}=\mathrm{Cl}$ or $\mathrm{Br})$ and those obtained for $\mathrm{Ba}_{2} \mathrm{Co}_{9} \mathrm{O}_{14}$ and $\mathrm{Ba}_{3} \mathrm{Co}_{10} \mathrm{O}_{17}$ viewed along [010]. It is thus possible to make an analogy with the compounds described by Sun et al:: in the oxyhalides, the $\left(\mathrm{Ba}_{2} \mathrm{Co}_{8} \mathrm{O}_{14}\right)^{2-}$ blocks are composed by a $\mathrm{CdI}_{2}$-type block and the "interface layer" of the $\mathrm{Ba}_{2} \mathrm{Co}_{9} \mathrm{O}_{14}$ and $\mathrm{Ba}_{3} \mathrm{Co}_{10} \mathrm{O}_{17}$ compounds. The main difference between these two classes of materials lies in the connection between the blocks: while in $\mathrm{Ba}_{2} \mathrm{Co}_{9} \mathrm{O}_{14}$ and $\mathrm{Ba}_{3} \mathrm{Co}_{10} \mathrm{O}_{17}$, the $\left(\mathrm{Ba}_{2} \mathrm{Co}_{8} \mathrm{O}_{14}\right)^{2-}$ blocks are linked together by one or two octahedra respectively (in white on Figure 2), in $\mathrm{Ba}_{2} \mathrm{Co}_{4} \mathrm{XO}_{7}$ they are clearly disconnected the ones from the others by double $\left(\mathrm{Ba}_{2} \mathrm{Cl}_{2}\right)^{2+}$ or $\left(\mathrm{Ba}_{2} \mathrm{Br}_{2}\right)^{2+}$ layers. One could thus imagine the formation of $\mathrm{Ba}_{2} \mathrm{Co}_{9} \mathrm{O}_{14}$ by removing the $\left(\mathrm{Ba}_{2} \mathrm{Cl}_{2}\right)^{2+}$ or $\left(\mathrm{Ba}_{2} \mathrm{Br}_{2}\right)^{2+}$ 
layers of $\mathrm{Ba}_{2} \mathrm{Co}_{4} \mathrm{XO}_{7}(\mathrm{X}=\mathrm{Cl}$ or $\mathrm{Br})$ and connecting the "interface layers" via an octahedral $\mathrm{CoO}_{6}$ slice. Such types of relations between oxides and oxyhalides have been recently reported in oxychlorides and oxybromides of ruthenium with hexagonal perovskite-type structures $[15,20]$.

Another way to describe the oxyhalides under study is to refer to the well known series of spinel oxides [21]. Indeed, spinel can be described as the alternate stacking of different types of polyhedral layers: a cation deficient octahedral layer (whose cationic lattice is called Kagomé, see hereafter) and a mixed layer built up from corner-sharing octahedra and tetrahedra. The $\left(\mathrm{Ba}_{2} \mathrm{Co}_{8} \mathrm{O}_{14}\right)^{2-}$ blocks can thus be described using the formalism developed for the spinel oxides:

- The central block is formed by the $(\mathrm{AB})$ stacking of $\left[\mathrm{O}_{4}\right]$ layers, thus creating a sheet of edge-sharing cobalt-octahedra (Figure 3a). This arrangement can be considered as a Kagomé lattice (Figure 3b), denoted in the literature $\left(\mathrm{Oc}_{3}\right)$, in which all octahedral sites are fully occupied. $\operatorname{Co}(1)$ atoms are in the real octahedral sites of the Kagomé lattice whereas $\operatorname{Co}(2)$ occupy the Kagomé windows. This distribution leads to a complete octahedral layer of the $\mathrm{CdI}_{2}$-type but with two different crystallographic sites for the cobalt atoms. By analogy to the $\left(\mathrm{Oc}_{3}\right)$ layer, we will note this fully occupied Kagomé lattice $\left(\mathrm{Oc}_{4}\right)$. Numerous compounds are constituted of $\left(\mathrm{Oc}_{3}\right)$ octahedral layers, like for example, the spinel oxide $\mathrm{MgAl}_{2} \mathrm{O}_{4}$ [22], the olivine ( $\mathrm{Mg}, \mathrm{Fe})_{2} \mathrm{SiO}_{4}[23]$ or the double hexagonal $\mathrm{LiFeSnO}_{4}[24]$. In the present compounds, the calculated valence bond sums for $\operatorname{Co}(1)$ and $\operatorname{Co}(2)$ indicate a $\operatorname{Co}(1)^{3+} / \operatorname{Co}(2)^{2+}$ distribution. Furthermore, the average Co-O bond lengths of 1.915(7) $\AA$ for $\operatorname{Co}(1)$ and 2.078(7) $\AA$ for $\mathrm{Co}(2)$ in $\mathrm{Ba}_{2} \mathrm{Co}_{4} \mathrm{ClO}_{7}\left(1.927(9) \AA\right.$ for $\mathrm{Co}(1)$ and $2.100(8) \AA$ for $\mathrm{Co}(2)$ in $\left.\mathrm{Ba}_{2} \mathrm{Co}_{4} \mathrm{BrO}_{7}\right)$ confirm the $\mathrm{Co}(1)^{3+} / \mathrm{Co}(2)^{2+}$ repartition with bond distances longer for $\mathrm{Co}^{2+}$ than for $\mathrm{Co}^{3+}$, in agreement with the charge distribution proposed in $\mathrm{Ba}_{2} \mathrm{Co}_{9} \mathrm{O}_{14}[9]$. 
- The second type of sheet is built up from corner-sharing octahedra and tetrahedra, resulting from the $(\mathrm{AB})$ stacking of $\left[\mathrm{O}_{4}\right]$ and $\left[\mathrm{BaO}_{3}\right]$ layers (Figure $\left.4 \mathrm{a}\right)$. Each tetrahedron is connected to three octahedra through the oxygen of the $\left[\mathrm{BaO}_{3}\right]$ layer. This mixed-polyhedra block can be considered as a $\left(\mathrm{Te}_{2} \mathrm{Oc}\right)$ layer (Figure $\left.4 \mathrm{~b}\right)$ in which one half of tetrahedral sites are empty. This kind of $(\mathrm{TeOc})$ layer has been already evidenced in the $\mathrm{LiLnMo}_{3} \mathrm{O}_{8}$ compound for example [25]. The bond valence sums calculation for octahedral $\mathrm{Co}(3)$ suggest a $\mathrm{Co}^{3+}$ valence state. The Co-O bond distance of $1.946(8) \AA$ for both $\mathrm{Ba}_{2} \mathrm{Co}_{4} \mathrm{ClO}_{7}$ and $\mathrm{Ba}_{2} \mathrm{Co}_{4} \mathrm{BrO}_{7}$ materials is similar to the $\operatorname{Co}(1)^{3+}-\mathrm{O}$ bond length of the Kagomé layer, confirming the suggested $\operatorname{Co}(3)^{3+}$ valence state. Finally, the BVS calculation for $\operatorname{Co}(4)$ indicates a slightly over-bonded character. However, as commonly observed is this kind of materials, one should note the possibility of oxygen vacancies, thus leading to a possible $\operatorname{Co}(4)^{2+}$ tetrahedral cobalt.

In the literature, two kinds of junction have been observed to connect an $\left(\mathrm{Oc}_{3}\right)$ block with a $\left(\mathrm{Te}_{2} \mathrm{Oc}\right)$ layer:

- the junction $\mathrm{J}_{\mathrm{K} / \mathrm{T}}$ is obtained by the occlusion of the Kagomé windows by a tetrahedron of the $\left(\mathrm{Te}_{2} \mathrm{Oc}\right.$ ) layer (Figure 5a). In this configuration, the tetrahedron shares three corners with the octahedra of the Kagomé windows. This kind of $\mathrm{J}_{\mathrm{K} / \mathrm{T}}$ junction is observed, for example, in the spinel oxide structure [22].

- the junction $\mathrm{J}_{\mathrm{K} / \mathrm{O}}$ exists when a Kagomé windows is blocked by an octahedron of the $\left(\mathrm{Te}_{2} \mathrm{Oc}\right)$ layer by sharing three corners (Figure $5 b$ ). This type of $J_{K / O}$ junction has been evidenced for double hexagonal $\mathrm{LiFeSnO}_{4}[24]$.

In the same manner, $J_{K / T}$ and $J_{K / O}$ junctions have been reported for connecting $\left(\mathrm{Oc}_{3}\right)$ and (TeOc) layers (Figure 5c and 5d). For example, in $\mathrm{LiLnMo}_{3} \mathrm{O}_{8}[25]$, the $\left(\mathrm{Oc}_{3}\right)$ and $(\mathrm{TeOc})$ layers are connected alternatively by $\mathrm{J}_{\mathrm{K} / \mathrm{T}}$ and $\mathrm{J}_{\mathrm{K} / \mathrm{O}}$ junctions. 
In the compounds reported here, the junction between $\left(\mathrm{Oc}_{4}\right)$ and $(\mathrm{TeOc})$ layers is ensured by sharing the corners of polyhedra, the oxygen atoms of $\left[\mathrm{O}_{4}\right]$ layers making the connexion between the two blocks. Central $\mathrm{O}(1)$ oxygen of tetrahedral $\mathrm{Co}(4)$ units is the common oxygen of three edge-sharing $\mathrm{Co}(1)$ octahedra while $\mathrm{O}(2)$ oxygen of octahedral $\operatorname{Co}(3)$ units ensures the connexion between three $\operatorname{Co}(2)$ octahedra. To our knowledge, it is the first time that this kind of junction is observed for the connection of $\left(\mathrm{Oc}_{3}\right)$-like $\left(=\left(\mathrm{Oc}_{4}\right)\right)$ and (TeOc) layers. In that way, the connections of polyhedral layers in $\mathrm{Ba}_{2} \mathrm{Co}_{4} \mathrm{ClO}_{7}$ and $\mathrm{Ba}_{2} \mathrm{Co}_{4} \mathrm{BrO}_{7}$, as compared to the different types of junctions previously reported in the literature, can be considered as a $\mathrm{J}_{\mathrm{K} / \mathrm{O}}$ junction translated by $(a+b) / 2$ (Figure $6 \mathrm{a}$ ), hereafter noted $\mathrm{J}_{\mathrm{K} / \mathrm{O}}{ }^{*}$. In summary, the $\left(\mathrm{Ba}_{2} \mathrm{Co}_{8} \mathrm{O}_{14}\right)^{2-}$ block viewed along [010] (Figure 6b) can be schematized as a $(\mathrm{TeOc})-\left(\mathrm{Oc}_{4}\right)-(\mathrm{TeOc})$ stacking, with a $\mathrm{J}_{\mathrm{K} / \mathrm{O}}{ }^{*}$ junction between each layer.

The $\left(\mathrm{Ba}_{2} \mathrm{Cl}_{2}\right)^{2+}$ double layers are completely related to the reference structure fluorite $\left(\mathrm{CaF}_{2}\right)$ [26]. This later consists of infinite planes of $\mathrm{Ca}$ and $\mathrm{F}$, thus making a compact framework of $\mathrm{FCa}_{4}$ tetrahedra. On Figure 7 is presented the $\left(\mathrm{Ba}_{2} \mathrm{Cl}_{2}\right)^{2+}$ block of $\mathrm{Ba}_{2} \mathrm{Co}_{4} \mathrm{ClO}_{7}$ viewed along [010] (a) and the fluorite structure viewed along [011] (b). One should note the perfect similitudes between the $\left(\mathrm{Ba}_{2} \mathrm{Cl}_{2}\right)^{2+}$ double layers and an isolated $\left(\mathrm{Ca}_{2} \mathrm{~F}_{2}{ }^{2+}\right)$ block of fluorite. In this way, we can consider the $\left(\mathrm{Ba}_{2} \mathrm{Cl}_{2}\right)^{2+}$ blocks in $\mathrm{Ba}_{2} \mathrm{Co}_{4} \mathrm{ClO}_{7}$ as fluorite-type double layers.

The $\left(\mathrm{Ba}_{2} \mathrm{Br}_{2}\right)^{2+}$ double layers of $\mathrm{Ba}_{2} \mathrm{Co}_{4} \mathrm{BrO}_{7}$ are strongly related to the $\left(\mathrm{Ba}_{2} \mathrm{Cl}_{2}\right)^{2+}$ blocks but with some interesting differences. While $\mathrm{Ba}(1)$ atoms occupy exactly the same position (6c), the positions of halides are modified, considering $\mathrm{Cl}$ or $\mathrm{Br}$ atoms. The most significant two- and three-dimensional electron density (ED) images in the region of the 
chlorine and bromine atoms are shown in Figure 8. These images clearly shows that while the chlorine atom $\mathrm{Cl}(1)$ is localised on its $6 c$ site (a), bromine is split over two distinct positions: $\operatorname{Br}(1)$ displays a triangular shape around a $6 c$ site (b), occupying a $18 \mathrm{~h}$ site at $25 \%$, and $\operatorname{Br}(2)$ is split on a $6 \mathrm{c}$ position occupied at $25 \%$ (c). Note that the occupations have been constrained together to fulfill the chemical composition $\mathrm{Ba}_{2} \mathrm{Co}_{4} \mathrm{BrO}_{7}$. In summary, atoms in the area of the $\left(\mathrm{Ba}_{2} \mathrm{Br}_{2}\right)^{2+}$ double layers are affected by a structural disorder, while the other atoms are well ordered. This aspect has already been pointed out for other compounds containing bromine atoms [15].

\section{Conclusion}

To summarize the main findings of the work presented here, we have determined the structures of two new isostructural cobaltites. They are built by the stacking of fluorite-type layers and interesting blocks containing $\left(\mathrm{CoO}_{2}\right)$ layers. The role of the halide seems to be of particular interest for the modification of the structures: replacing the chlorine by a bromine atoms leads to the creation of disordered layers. This last point confirms the previously studies made on barium ruthenates with either chlorine- or bromine-based layers [15, 20]. Syntheses of pure powders suitable for a full physical characterization are in progress.

\section{Supporting Information Available:}

Further details concerning the nuclear structures determinations and the Maximum Entropy Method analysis may be obtained upon request from the authors. 


\section{Acknowledgements:}

M. K. is indebted to "CNRS" and "Région Nord Pas-de-Calais" for financial support. The "Fonds Européen de Développement Régional (FEDER)", "CNRS”, "Région Nord Pasde-Calais" and «Ministère de l'Education Nationale, de l'Enseignement Supérieur et de la Recherche" are acknowledged for fundings of X-ray diffractometers. The authors want to thank Dr Olivier Mentré for fruitful discussion. 


\section{References:}

[1] Galasso F.S., Perovskites and High T Superconductors, Gordon \& Breach, Science Publishers Ltd, New York, 1990

[2] Rao C.N.R., Cheetham A.K., Mahesh R., Chem. Mater. 8 (10) (1996) 2421

[3] Von Helmot R., Holzapfel B., Schultz L., Samwer K., Phys. Rev. Lett. 71 (1994) 2331

[4] Caignaert V., Maignan A., Raveau B., Solid State Commun. 95 (1995) 357

[5] Korotin M., Ezhov S., Solovyev I., Anisimov V., Khomskii D., Sawatzky G.A., Phys. Rev. B 54 (1996) 5309

[6] Goodenough J.B., Demazeau G., Pouchard M., Hagenmuller P., Solid State Chem. 8 (1973) 325

[7] Maignan A., Caignaert V., Raveau B., Khomskii D., Sawatzky G.A., Phys. Rev. Lett. 93 (2004) 026401

[8] Terasaki I., Sasago Y., Uchinokura K., Phys. Rev. B 56 (1997) R12685

[9] Sun J., Yang M., Li G., Yang T., Liao F., Wang Y., Xiong M., Lin J., Inorg. Chem. 45 (2006) 9151

[10] Maignan A., Wang L., Hébert S., Pelloquin D., Raveau B., Chem. Mater. 14 (2002) 1231

[11] Bruker Analytical X-ray system, “'SAINT+, Version 7.12”, Madison USA (2004)

[12] Scheldrick G.M., SADABS, Bruker-Siemens Area Detector Absorption and Other Correction, Version 2006/1, Goetingen Germany (2006)

[13] Altomare A., Burla M.C., Camalli M., Cascarano G., Giacovazzo C., Guagliardi A., Moliterni A.G.G., Polidori G., Spagna R., SIR97 A Package for Crystal Structure Solution by Direct Methods and Refinement, Bari Rome Italy (1997)

[14] Petricek V., Dusek M., Palatinus L., The Crystallographic Computing System JANA2000, Praha Czech Republic (2005) 
[15] Kauffmann M., Roussel P., Abraham F., submitted to J. Solid State Chem. (2007)

[16] Bagautdinov B., Luedecke J., Schneider M. and van Smaalen S. Acta Cryst. B 54 (1998) 626

[17] Palatinus L., Van Smaalen S., BAYMEM - A computer program for application of the Maximum Entropy Method in reconstruction of electron densities in arbitrary dimension (2005)

[18] Katz L., Ward R., Inorg. Chem. 3 (1964) 205

[19] Ehora G., Daviero-Minaud S., Colmont M., André G., Mentré O., accepted in Chem. Mat. (2007)

[20] Tancret N., Roussel P., Abraham F., J. Solid State Chem. 177 (2004) 806

[20] Ward R. Progress in Inorganic Chemistry, Vol. 1, Cotton F.A. Ed., Interscience, New York, 1959, p 465

[21] Fischer P., Zeitschrift fuer Kristallographie, Kristallgeometrie, Kristallphysik, Kristallchemie 124 (1967) 275

[22] Futerglender M., Kristallografiya 3 (1958) 494

[23] Choisnet J., Hervieu M., Raveau B., Tarte P., J. Solid State Chem. 40 (1981) 344

[24] Strobel P., Le Page Y., McAlister S.P., J. Solid State Chem. 42 (1982) 242

[25] Gerlach W., Physical Review 19 (1925) 248 


\section{Figure Caption}

Figure 1: View along [010] of (a) $\mathrm{Ba}_{2} \mathrm{Co}_{4} \mathrm{ClO}_{7}$ and (b) $\mathrm{Ba}_{2} \mathrm{Co}_{4} \mathrm{BrO}_{7}$

Figure 2: View along [010] of (a) $\mathrm{Ba}_{2} \mathrm{Co}_{4} \mathrm{XO}_{7}$, (b) $\mathrm{Ba}_{2} \mathrm{Co}_{9} \mathrm{O}_{14}$ and (c) $\mathrm{Ba}_{3} \mathrm{Co}_{10} \mathrm{O}_{17}$. The $\left(\mathrm{Ba}_{2} \mathrm{Co}_{8} \mathrm{O}_{14}\right)^{2-}$ blocks encountered in the two series are encircled with dotted lines.

Figure 3: Schematic representations of (a) central block of edge-sharing octahedra $\left(\mathrm{Oc}_{4}\right)$ of $\mathrm{Ba}_{2} \mathrm{Co}_{4} \mathrm{ClO}_{7}$ and $\mathrm{Ba}_{2} \mathrm{Co}_{4} \mathrm{BrO}_{7}$ and (b) true Kagomé lattice $\left(\mathrm{Oc}_{3}\right)$ with its windows

Figure 4: Schematic representations of mixed layers built up from corner-sharing octahedra and tetrahedra (a) (TeOc) layer of $\mathrm{Ba}_{2} \mathrm{Co}_{4} \mathrm{ClO}_{7}$ and $\mathrm{Ba}_{2} \mathrm{Co}_{4} \mathrm{BrO}_{7}$ and (b) $\left(\mathrm{Te}_{2} \mathrm{Oc}\right)$ layer

Figure 5: Schematic representations of the different types of junctions: (a) $J_{K / T}$ between $\left(\mathrm{Oc}_{3}\right)$ and $\left(\mathrm{Te}_{2} \mathrm{Oc}\right)-(\mathrm{b}) \mathrm{J}_{\mathrm{K} / \mathrm{O}}$ between $\left(\mathrm{Oc}_{3}\right)$ and $\left(\mathrm{Te}_{2} \mathrm{Oc}\right)-(\mathrm{c}) \mathrm{J}_{\mathrm{K} / \mathrm{T}}$ between $\left(\mathrm{Oc}_{3}\right)$ and $(\mathrm{TeOc})-(\mathrm{d})$ $\mathrm{J}_{\mathrm{K} / \mathrm{O}}$ between $\left(\mathrm{Oc}_{3}\right)$ and $(\mathrm{TeOc})$

Figure 6: Schematic representation of $\left(\mathrm{Ba}_{2} \mathrm{Co}_{8} \mathrm{O}_{14}\right)^{2-}$ block (a) viewed along (001) and (b) viewed along (010)

Figure 7: Schematic representation of (a) $\left(\mathrm{Ba}_{2} \mathrm{Cl}_{2}\right)^{2+}$ block viewed along [010] and (b) structure reference fluorite viewed along [011]

Figure 8: Two- and three-dimensional electron density (ED) images for (a) $\mathrm{Cl}(1)$ atom, (b) $\operatorname{Br}(1)$ atom and (c) $\operatorname{Br}(2)$ atom 


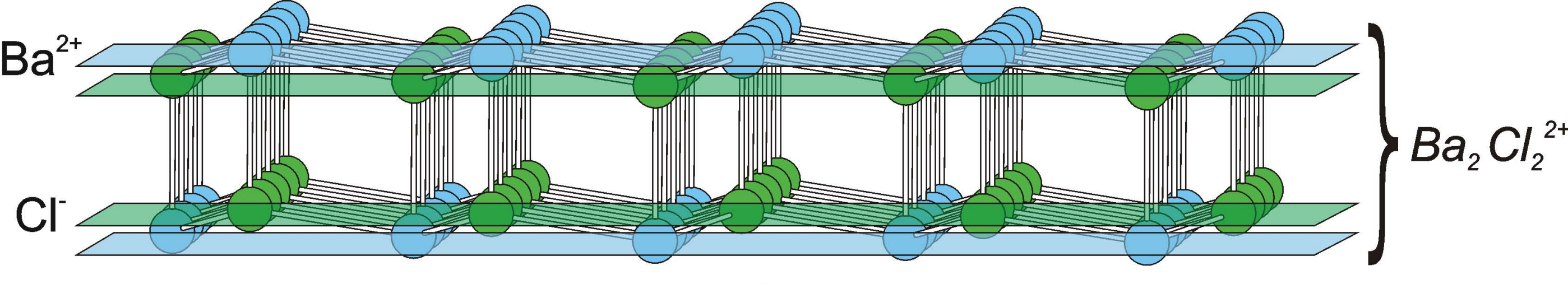

\section{(a)}

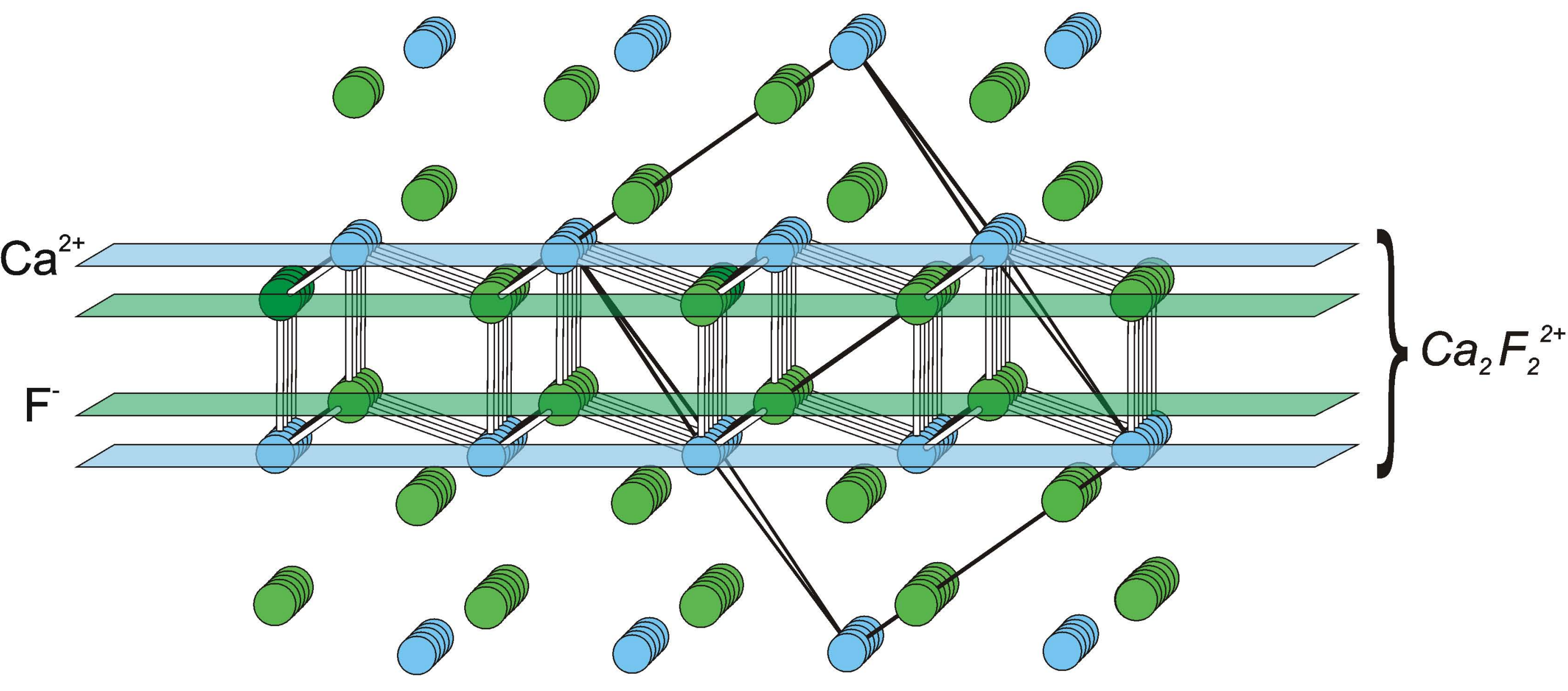

(b) 

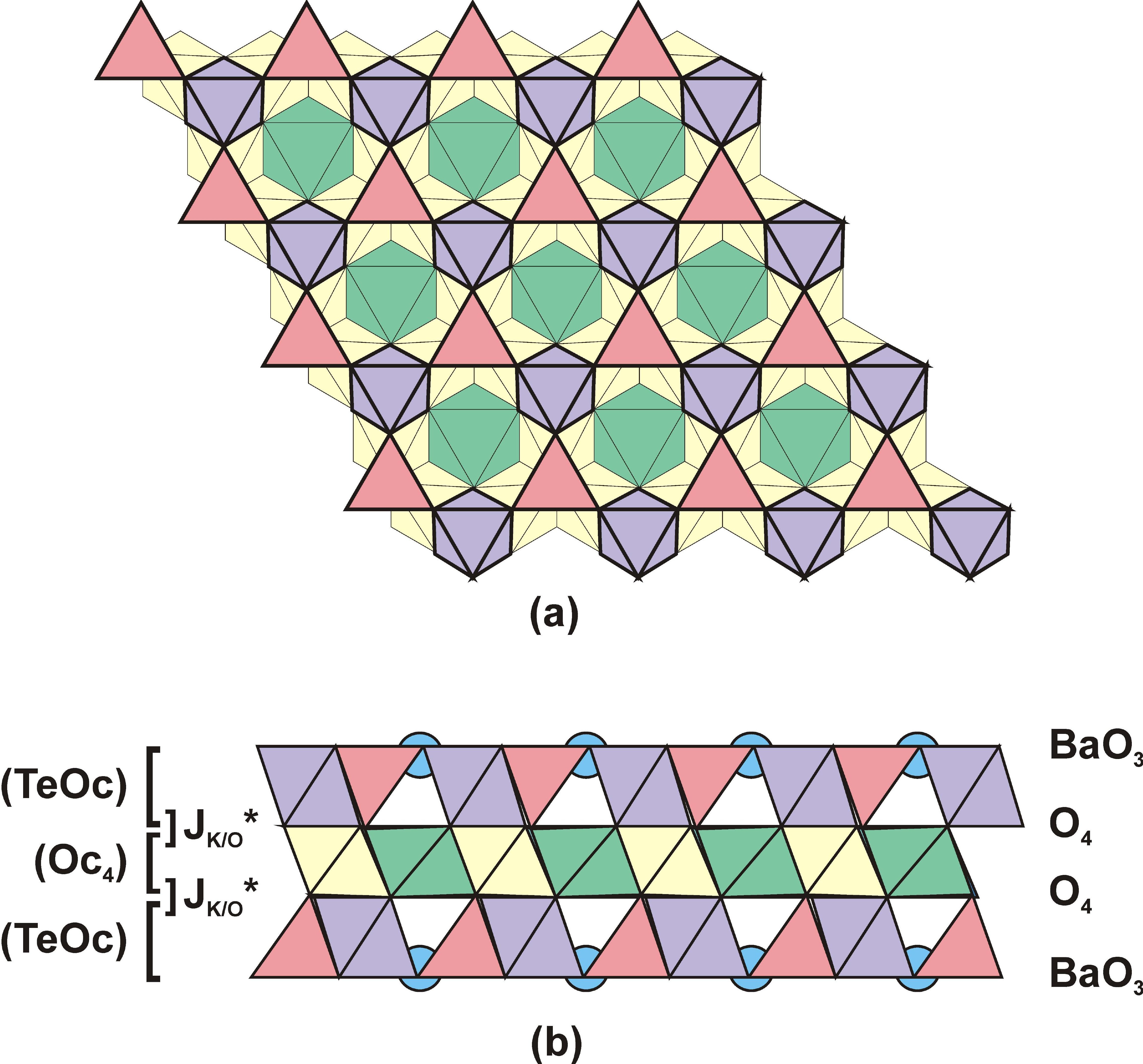


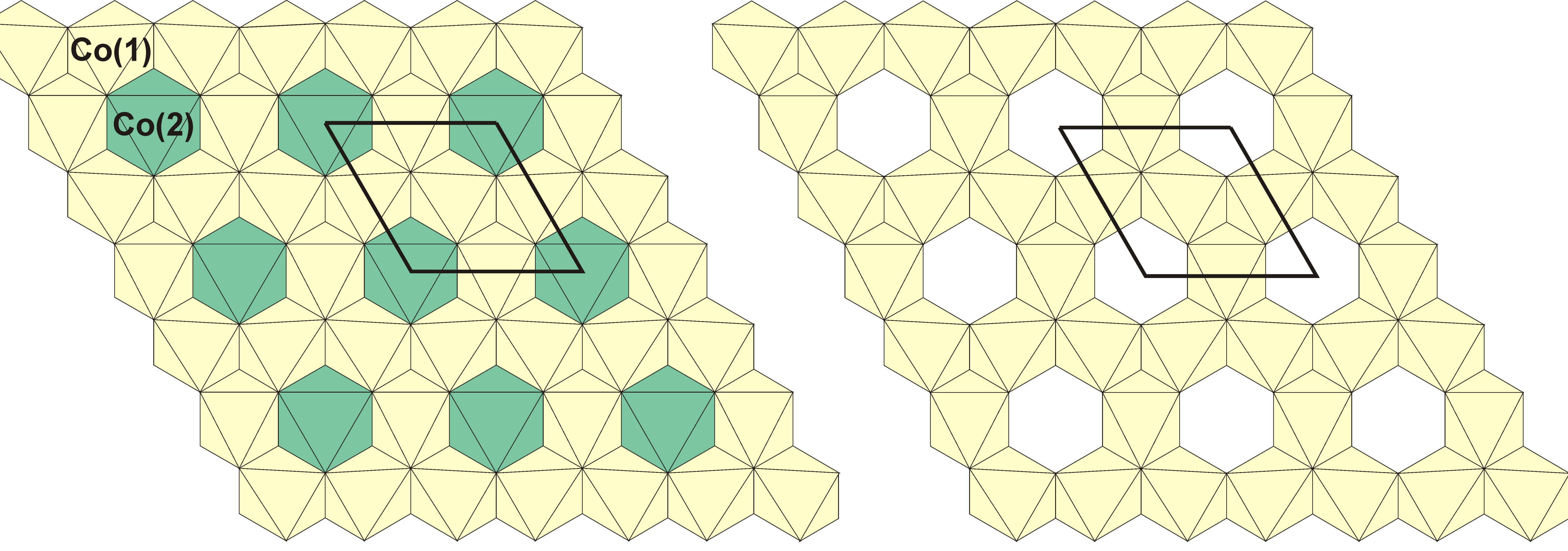

(a) - $\left(\mathrm{Oc}_{4}\right)$ layer

(b) - $\left(\mathrm{Oc}_{3}\right)$ layer 


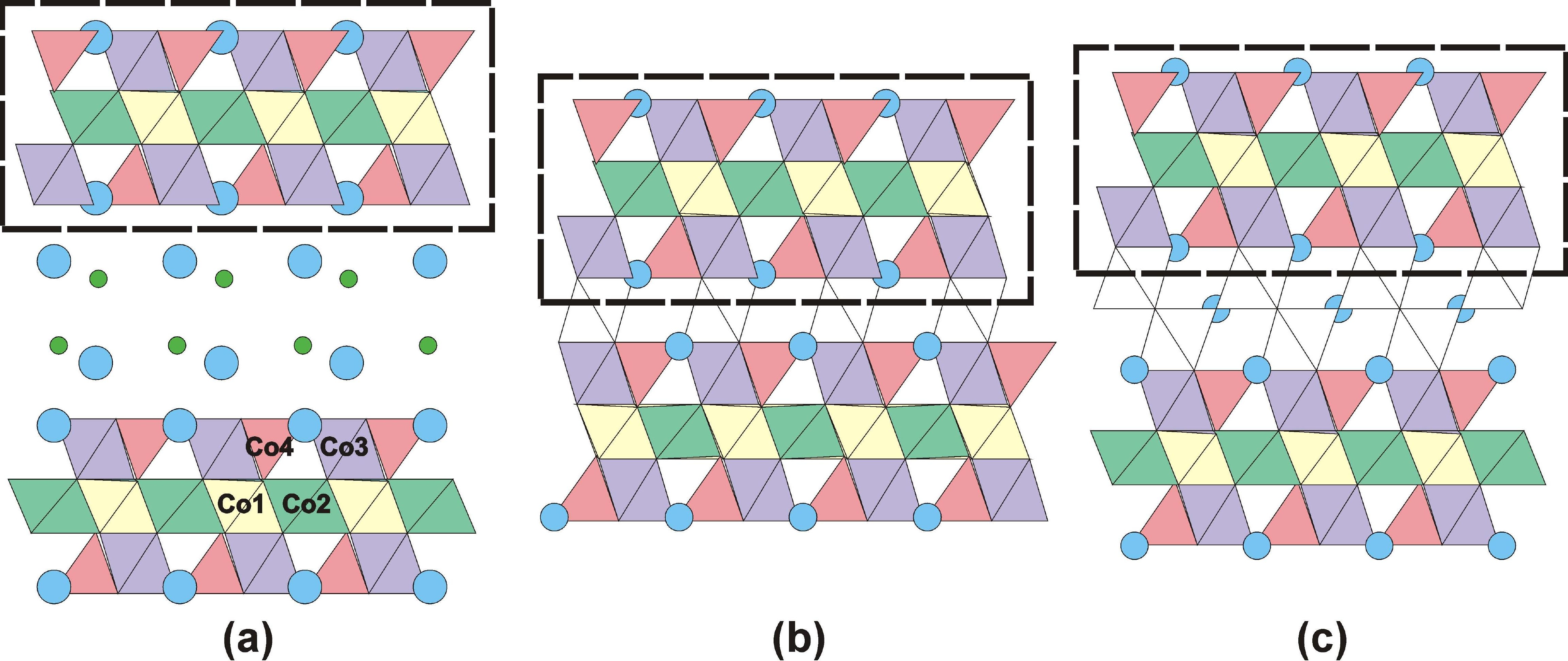




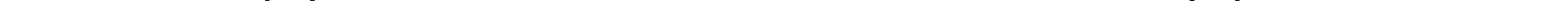



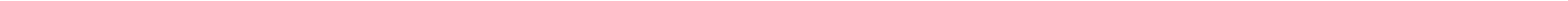